\title{
Immunotherapy and immunochemotherapy in visceral leishmaniasis: promising treatments for this neglected disease
}

\section{Bruno Mendes Roatt 1,2,3 *, Rodrigo Dian de Oliveira Aguiar-Soares ${ }^{1}$, Wendel Coura-Vital ${ }^{1,2}$, Henrique Gama Ker ${ }^{1,2}$, Nádia das Dores Moreira ${ }^{1}$, Juliana Vitoriano-Souza ${ }^{1}$, Rodolfo Cordeiro Giunchetti ${ }^{14}$, Cláudia Martins Carneiro ${ }^{1,2}$ and Alexandre Barbosa Reis ${ }^{1,2,3 *}$}

\footnotetext{
${ }^{1}$ Laboratório de Imunopatologia, Núcleo de Pesquisas em Ciências Biológicas, Universidade Federal de Ouro Preto, Ouro Preto, Brazil

${ }^{2}$ Laboratório de Pesquisas Clínicas, Ciências Farmacêuticas, Escola de Farmácia, Universidade Federal de Ouro Preto, Ouro Preto, Brazil

${ }^{3}$ Instituto Nacional de Ciência e Tecnologia em Doenças Tropicais, Belo Horizonte, Brazil

${ }^{4}$ Laboratório de Biologia das Interações Celulares, Departamento de Morfologia, Universidade Federal de Minas Gerais, Belo Horizonte, Brazil
}

Edited by:

Nahid Ali, Indian Institute of Chemical

Biology, India

Reviewed by:

Emilio Luis Malchiodi, University of

Buenos Aires, Argentina

Paula Mello De Luca, Funfação

Oswaldo Cruz, Brazil

Jesus G. Valenzuela, National Institute

of Allergy and Infectious Diseases,

USA

*Correspondence:

Bruno Mendes Roatt and Alexandre

Barbosa Reis, Laboratório de

Imunopatologia, Núcleo de Pesquisas

em Ciências Biológicas, ICEB II,

Campus Morro do Cruzeiro,

Universidade Federal de Ouro Preto,

Ouro Preto, Minas Gerais CEP

35400-000, Brazil

e-mail: eroatt@nupeb.ufop.br;

alexreis@nupeb.ufop.br
Leishmaniasis has several clinical forms: self-healing or chronic cutaneous leishmaniasis or post-kala-azar dermal leishmaniasis; mucosal leishmaniasis; visceral leishmaniasis (VL), which is fatal if left untreated. The epidemiology and clinical features of $V L$ vary greatly due to the interaction of multiple factors including parasite strains, vectors, host genetics, and the environment. Human immunodeficiency virus infection augments the severity of VL increasing the risk of developing active disease by 100-2320 times. An effective vaccine for humans is not yet available. Resistance to chemotherapy is a growing problem in many regions, and the costs associated with drug identification and development, make commercial production for leishmaniasis, unattractive. The toxicity of currently drugs, their long treatment course, and limited efficacy are significant concerns. For cutaneous disease, many studies have shown promising results with immunotherapy/immunochemotherapy, aimed to modulate and activate the immune response to obtain a therapeutic cure. Nowadays, the focus of many groups centers on treating canine $V L$ by using vaccines and immunomodulators with or without chemotherapy. In human disease, the use of cytokines like interferon- $\gamma$ associated with pentavalent antimonials demonstrated promising results in patients that did not respond to conventional treatment. In mice, immunomodulation based on monoclonal antibodies to remove endogenous immunosuppressive cytokines (interleukin-10) or block their receptors, antigen-pulsed syngeneic dendritic cells, or biological products like Pam3Cys (TLR ligand) has already been shown as a prospective treatment of the disease. This review addresses $V L$ treatment, particularly immunotherapy and/or immunochemotherapy as an alternative to conventional drug treatment in experimental models, canine $\mathrm{VL}$, and human disease.

Keywords: visceral leishmaniasis, immunology, immunotherapy, immunochemotherapy, Leishmania infantum, Leishmania donovani

\section{INTRODUCTION OF VISCERAL LEISHMANIASIS: EPIDEMIOLOGY OF A ZOONOTIC AND ANTHROPONOTIC NEGLECTED DISEASE}

Visceral leishmaniasis (VL) is a severe chronic systemic disease caused by Leishmania donovani or $L$. infantum. Occasionally, $L$. tropica in the Middle East and L. amazonensis in South America can produce VL (1). Leishmania spp. are transmitted to human and animal hosts through the bite of female sand flies from the genera Phlebotomus in the Old World and Lutzomyia in the New World (2). Depending on whether or not a reservoir host is present, there are two basic types of epidemiological cycles: zoonotic, generally caused by L. infantum, which occurs in the Mediterranean Basin, China, the Middle East, and South America, and anthroponotic, generally caused by L. donovani, which is prevalent in East Africa, Bangladesh, India, and Nepal (3). The dogs, independent of the clinical form of VL, are the main urban reservoirs of $L$. infantum and represent the major source of contagion for the vectors by virtue of the high prevalence of infection and intense cutaneous parasitism $(4,5)$.

Canine visceral leishmaniasis (CVL) is present in approximately 50 countries, mainly in South America, the Mediterranean region, and Africa $(6,7)$. Several reports have revealed the emergence of canine infection in new locations, such as the United States and Canada $(8,9)$, and a northward spread in Europe, as found in Italy $(10,11)$. The seroprevalence of CVL ranges between 2 and $25 \%$ in endemic areas of Europe (2) and 5.9 and $29.8 \%$ in Brazil (12). In recent years, with the development of molecular techniques, infection rates have been shown to be underestimated. Studies in Europe have demonstrated an elevated prevalence of CVL $(60-80 \%)$ by polymerase chain reaction (PCR) compared 
with serology (25\%) (13). During a cross-sectional study in an urban area of Brazil, we observed that approximately a quarter of seronegative dogs were infected by L. infantum according to PCR (14), and they had approximately twice the risk of seroconversion as those that were PCR negative (15). Finally, a high incidence of infection was demonstrated by PCR in endemic areas (16).

Official global estimates indicate that there are more than 58,000 cases of human VL (HVL) per year. However, the number may actually be as high as $0.2-0.4$ million, and more than $90 \%$ of cases occur in five countries: India, Bangladesh, Sudan, Brazil, and Ethiopia (17). The incidence of VL is relatively low in southern Europe (2), but the disease has recently spread further northward as shown by reports of cases in northern Italy (18) and Germany (19). Additionally, the epidemiology of the disease has been influenced by the expansion of human immunodeficiency virus (HIV). Of the 70 countries that are endemic for VL, 35 have reported cases of Leishmania-HIV co-infection (20). One of the critical complications associated with co-infection is that HIV reduces the likelihood of a therapeutic response to treatment against $L$. infantum, and it also greatly increases the probability of a relapse (21).

Visceral leishmaniasis is clinically characterized by prolonged fever, weakness, anorexia, weight loss, hepatomegaly, splenomegaly, hypergammaglobulinemia, and pancytopenia. Without treatment, the disease may progress over time to severe cachexia, multisystem disease, bleeding, secondary infections, and death $(22,23)$. The case-fatality rates range from $1.5 \%$ in Bangladesh to $2.4 \%$ in India and $6.2 \%$ in Nepal (17). However, studies conducted by Ahluwalia et al. (24) in Bangladesh and by Barnett et al. (25) in India suggest that the rates are probably underestimated. In Brazil, data from the Ministry of Health were used to estimate $6.5 \%$ mortality from 2001 to 2011 (26). VL results in death mainly in untreated patients. The majority of leishmaniasis deaths go unrecognized, and even with treatment access, case-fatality rates can be as high as $10-20 \%$ (17). These findings underscore the need for further studies on the development of immunotherapeutic and prophylactic strategies for VL and Leishmania-HIV co-infection.

In this review, we discuss the recent advances in immunotherapy and immunochemotherapy in the treatment of VL, focusing on both canine and human disease and experimental models (murine). We also discuss some aspects of the epidemiology and immunology of VL, the most recent strategies and guidelines for chemotherapy, and new advances in modulating the host immune response (collectively called immunotherapy) with or without conventional chemotherapy.

\section{IMMUNOBIOLOGY OF VISCERAL LEISHIMANIASIS: CELLS AND IMMUNE MEDIATORS RELATED TO RESISTANCE AND SUSCEPTIBILITY}

In visceral disease, the immunology and immunopathology in humans, dogs, and experimental rodent models has been extensively studied, with many points characterized and others still to be elucidated (27-29). A general consensus is that despite the peculiarities of each model, the outcome of the disease is critically influenced by the host immune response.
Several studies have demonstrated that susceptibility to HVL is related to a high titer of circulating antibodies and a depression of type-1 T cell-mediated immunity, mainly with decreased production of interferon (IFN) $-\gamma$ and interleukin (IL)-12, including a marked up-regulation of IL-4 and IL-10 cytokines (30-32). In CVL, the protective response has also been associated with activation of Th1 cells producing IFN- $\gamma$, IL-2, and tumor necrosis factor (TNF)- $\alpha(33,34)$. Similar to HVL, active CVL is characterized by polyclonal B-cell activation, specific immunosuppression, and the appearance of clinical symptoms depending on the parasite density in different visceral organs $(35,36)$. An interplay of Th1 and Th2 cytokines appears to exist during Leishmania infection, and this suggests important roles for different cytokines in disease protection and pathogenesis (37).

The innate immune response contributes to VL resistance, acting to control parasite growth during the early stages of infection. Furthermore, it directs cell recruitment and helps develop the cytokine microenvironment in which parasite-specific T cells are primed $(38,39)$.

The control of VL infection depends on a successful cellmediated immune response (40), in which IFN- $\gamma$, produced mainly by $\mathrm{CD}^{+}{ }^{+} \mathrm{T}$ cells and natural killer $(\mathrm{NK})$ cells stimulated by IL-12, leads to stimulation of microbicide action mediated by nitric oxide $(41,42)$. TNF- $\alpha$ exerts cytotoxic effects on invading parasites via its receptor, TNFR (43). There have been reports of the involvement of different Th17 cytokines in HVL, including IL-17, IL-22 (44), and IL-21 (45), which are important in the migration, recruitment, and activation of neutrophils. Recent work of Gautam et al. (46) evaluating patients with VL showed that individuals with active disease exhibit predominantly anergic splenic CD8 cells and CD8 peripheral blood mononuclear cells (PBMCs) with a mixture of anergic cells and cytotoxic T lymphocytes (CTLs). Following a cure after treatment, CD8 T cells contribute to Leishmania-induced IFN- $\gamma$ production. The authors suggested that CD8 $\mathrm{T}$ cells are driven to anergy/exhaustion in HVL, which affects their ability to launch a protective immune response (46).

The expression of the various chemokine genes is observed in Leishmania infection $(47,48)$. Chemokines have been shown to play a crucial role in determining the outcome of leishmaniasis by coordinating the leukocyte recruitment involved in innate and adaptive immune responses $(49,50)$. Patients with VL show elevated concentrations of CXCL9 and CXCL10 in their serum during active infection, and it has been suggested that these chemokines play an important role along with IFN- $\gamma$ in the disease (51). Dogs naturally or experimentally infected with L. infantum have CXCL10 mRNA overexpressed in the spleen, leading to a substantial type-1 immune response (52). A detailed analysis of chemokine expression in skin samples from dogs naturally infected with $L$. infantum demonstrated enhanced parasite density and a positive correlation with CCL2, CCL4, CCL5, CCL21, and CXCL8 (49). It is noteworthy that some chemokines such as CCL2 can activate macrophages to participate in reducing the parasite load (53).

The monocytes/macrophages, the main targets of Leishmania, represent one of the first steps of the innate immune response to kill intracellular parasite (54). The survival of the parasite relies 
on evasion mechanisms such as the modulation of leishmanicidal activity of macrophages by production of tumor growth factor (TGF)- $\beta$ with deactivation, inhibition of the action of IFN- $\gamma$, reduced expression of MHC class II molecules, and suppression of nitric oxide production (55). IL-10 is another cytokine produced by macrophages that contributes to the survival of Leishmania in these cells, and it has emerged as the most potent factor for VL pathogenesis. It inhibits synthesis of cytokines produced by macrophages, such as IL- $1 \beta$, IL-6, IL- 8 , and TNF- $\alpha$ (56) and reduces the antigen-presenting function of these cells by decreasing the expression of MHC class II molecules (57). The association of IL-10 and VL in humans with active disease is wellestablished (32). Others cytokines, such as IL-27 and IL-21, have also emerged as being implicated in disease progression through the regulation of IL-10 (45). Other cells, such as NK cells, are important components of the immune response to combat infection. They connect the innate response to the development of efficient adaptive cellular immunity, mainly through TNF- $\alpha$ and IFN- $\gamma$ production (58).

Successful immunity against Leishmania involves a complex immunological response of several mechanisms and factors, including the migration of appropriate cell populations to the infected sites, cytokine microenvironment, chemokines, and others. The elucidation and a better understanding of the immune response against Leishmania infection are relevant to establish a rational approach for immunomodulatory therapy and vaccine development.

\section{CONVENTIONAL VL THERAPY}

The drug policy in endemic countries and therapeutic decisions should be based on the individual benefit-risk ratio of drugs, the health service setting, and the availability of anti-leishmanial medicines in the context of public health concerns and the difference of the VL epidemiological aspects (anthroponotic and zoonotic) (59). For example, $70 \%$ of the anthropozoonotic VL burden occurs in the Indian subcontinent (17), and a critical challenge is related to widespread resistance to pentavalent antimony; resistance rates approach 60\% in Bihar, India (60). In Europe, Asia, Africa, and the Americas, where zoonotic cases are observed, the risk of human disease is well-known to be associated with canine infection rates (61). Another serious problem that mainly occurs with zoonotic $\mathrm{VL}$ is that canine treatment does not effectively lead to a parasitological cure since these animals are constant sources of infection for sand flies (36).

Nevertheless, a few drugs are available. In most cases, the firstline treatment is pentavalent antimonials, and amphotericin B or pentamidine are commonly employed as second-line medicines. In recent years, other medicines have been extensively studied and became invaluable, such as liposomal amphotericin B (62), miltefosine $(63,64)$, and paromomycin (65). In line with this, current World Health Organization (WHO) treatment advice varies by global region, which is partially explained by differences in parasite susceptibility $(59,66,67)$ (Table 1 ). Even so, the number of VL cases is increasing worldwide, and the enduring problems with current chemotherapy tools are still a critical issue. Furthermore, in many developing countries the cost of treatment is the greatest challenge faced by health authorities (Table 2). In the following section, we briefly review conventional chemotherapy, stressing essential issues in HVL and studies using different drugs and strategies for canine disease.

\section{PENTAVALENT ANTIMONIALS}

It is generally accepted that pentavalent antimonials $\left(\mathrm{Sb}^{\mathrm{V}}\right)$ are the pro-drug, and that they must convert to trivalent antimonials $\left(\mathrm{Sb}^{\mathrm{III}}\right)$ to have anti-leishmanial activity. The issues with the use of this drug are commonly attributed to serious side effects such as cardiotoxicity (68), pancreatitis (69), and nephrotoxicity (70). The doses and treatment durations of $\mathrm{Sb}^{\mathrm{V}}$ have undergone constant changes over the years. The use of $\mathrm{Sb}^{\mathrm{V}}$ in canine therapy does not lead to clinical and parasitological cure (71), and disease relapses are common (72). Moreover, prolonged or repeated use of this drug can induce resistance in Leishmania clones (73). Currently, an important strategy for therapy in dogs is the use of liposome-encapsulated $\mathrm{Sb}^{\mathrm{V}}$, which promotes improved clinical status and reduced parasite load in infected animals (74).

\section{AMPHOTERICIN B DEOXYCHOLATE AND LIPOSOMAL AMPHOTERICIN B}

The anti-Leishmania activity by amphotericin B is due to its complexation with 24-substituted sterols such as ergosterol and episterol, which are predominant in the plasma membranes of parasites. Amphotericin B deoxycholate is generally used for cases that are unresponsive to $\mathrm{Sb}^{\mathrm{V}}$, and it is a first-line drug in India. Unresponsiveness and relapses occur rarely and mostly in relation to HIV co-infection (75). The major limitation to using this drug is the necessity for prolonged hospitalization and close monitoring due to its high nephrotoxicity (76). The liposomal formulation improves the safety profile of amphotericin B and increases the anti-leishmanial activity, with selectivity to macrophage reticularendothelial system (77). There are three formulations, liposomal amphotericin B, amphotericin B lipid complex, and amphotericin B cholesterol dispersion; all of which ensure a decrease in nephrotoxicity. Currently, liposomal amphotericin B is the first treatment choice for HVL in several endemic countries in Europe as well as in the United States. Following other countries, the Ministry of Health in Brazil, expanded the use of this medicine in the last years. In dogs, therapy with amphotericin B deoxycholate reduces serum antibody levels and parasite loads and increases the lymphoproliferative response, but the effects are transitory (78). In addition, renal failure is a common outcome (79), and the drug is not recommended for canine therapy. Treatment with liposomal amphotericin B resulted in recovery in dogs, but despite the initial effectiveness, relapses can occur $(78,80)$.

\section{MILTEFOSINE}

Miltefosine, which was initially developed as an anticancer drug, is the first effective oral drug for VL, and it represents a great breakthrough $(81,82)$. The main anti-leishmanial activity is due to modulation of cell surface receptors, inositol metabolism, phospholipase activation, and protein kinase $\mathrm{C}$ in addition to mitogenic pathways resulting in apoptosis (83). The main side effects of the drug include gastrointestinal disturbances, but the symptoms are transient or reversible; however, teratogenicity is a major problem (84). Careful use of this drug should be mandatory, since resistance 
Table 1 | Recommendations of the World Health Organization for the treatment of visceral leishmaniasis per geographic region ranked by preference [World Health Organization (59)].

\section{ANTHROPONOTIC VISCERAL LEISHMANIASIS CAUSED BY L. donovani INTHE INDIAN SUBCONTINENT}

Liposomal amphotericin B: 3-5 mg/kg daily over 3-5 days to a total dose of $15 \mathrm{mg} / \mathrm{kg}$ by infusion or $10 \mathrm{mg} / \mathrm{kg}$ as a single dose

Combination therapy (co-administered following the sequence): (i) liposomal amphotericin B ( 5 mg/kg by infusion, single dose) + miltefosine (daily for

7 days, dosage as below), (ii) liposomal amphotericin B (5 mg/kg by infusion, single dose) + paromomycin (daily for 10 days, dosage as below), (iii),

miltefosine + paromomycin both for 10 days (dosages as below)

Amphotericin B deoxycholate: $0.75-1.0 \mathrm{mg} / \mathrm{kg}$ daily or on alternate days for $15-20$ doses by infusion

Miltefosine: children aged 2-11 years, $2.5 \mathrm{mg} / \mathrm{kg}$ daily; 12 years and older $<25 \mathrm{~kg}$ body weight, $50 \mathrm{mg} / \mathrm{day} ; 25-50 \mathrm{~kg}, 100 \mathrm{mg} / \mathrm{day} ;>50 \mathrm{~kg}, 150 \mathrm{mg} / \mathrm{day}$; orally for 28 days

Paromomycin: $15 \mathrm{mg}$ (11 mg base)/kg/day by intramuscular route for 21 days

Pentavalent antimonials: $20 \mathrm{mg} \mathrm{SbV} / \mathrm{kg} /$ day intramuscularly or by infusion for 30 days (areas where they are effective: Bangladesh, Nepal, and the Indian states of Jharkhand, West Bengal, and Uttar Pradesh)

\section{VISCERAL LEISHMANIASIS CAUSED BY L. donovani IN EAST AFRICA}

Combination therapy: pentavalent antimonials (20 mg SbV/kg/day intramuscularly or by infusion) + paromomycin [15 mg (11 mg base)/kg/day by

intramuscular route] for 17 days

Pentavalent antimonials: same treatment scheme as above

Liposomal amphotericin B: 3-5 mg/kg daily given over 6-10 days for a total dose of $30 \mathrm{mg} / \mathrm{kg}$ by infusion

Amphotericin B deoxycholate: same treatment scheme as above

Miltefosine: same treatment scheme as above

VISCERAL LEISHMANIASIS CAUSED BY L. infantum

Liposomal amphotericin B: 3-5 mg/kg daily over 3-6 days for a total dose of $18-21 \mathrm{mg} / \mathrm{kg}$ by infusion

Pentavalent antimonials: $20 \mathrm{mg} \mathrm{Sb} / \mathrm{kg} /$ day intramuscularly or by infusion for 28 days

Amphotericin B deoxycholate: $0.75-1.0 \mathrm{mg} / \mathrm{kg}$ daily or on alternate days for 10-20 doses by infusion (total dose: $2-3 \mathrm{~g}$ )

can be easily induced in in vitro experiments (85). Miltefosine has recently emerged as a potential tool for CVL treatment, and its use has been evaluated in monotherapy and in combination with other drugs $(86,87)$. There are no nephrotoxic effects reported, and vomiting is the most common side effect in dogs (88).

\section{PAROMOMYCIN}

Paromomycin presents variable efficacy in distinct parts of the world (89). The drug's low-cost, relatively short duration of administration, and good safety profile strengthens its usefulness as a first-line drug (90). The drug has activity against Leishmania by altering plasma membrane fluidity, interfering in ribosomal function, and disrupting mitochondrial membrane potential (91). The most common side effects associated with paromomycin are ototoxicity and impaired liver function (92). Although it is the least expensive drug for VL, current demand for paromomycin is low, and production is irregular. In canine studies, the drug was associated with a decrease in anti-Leishmania IgG antibody titers (93). Following clinical recovery, relapse, and parasitologic cure in symptomatic CVL treated with paromomycin, only clinical improvement was verified (94). However, the search for an optimum dosage for the safe use in the treatment of CVL is necessary.
Table 2 | Cost of visceral leishmaniasis treatment (patient weighing $35 \mathrm{~kg})^{*}$.

Medicine (compound)

\begin{tabular}{cc}
$\begin{array}{c}\text { Treatment regimen } \\
\text { in days }\end{array}$ & $\begin{array}{c}\text { Drug cost } \\
\text { in US\$ }\end{array}$ \\
\hline 1 & 125 \\
$2-4$ & 250 \\
30 & 20 \\
& \\
28 & $65-150$ \\
21 & 15 \\
30 & 55 \\
30 & 59 \\
8 & $88-109$ \\
11 & 78 \\
10 & $30-60$ \\
17 & 43
\end{tabular}

\section{L-Amb $10 \mathrm{mg} / \mathrm{kg}$}

L-Amb $20 \mathrm{mg} / \mathrm{kg}$

Amphotericin B deoxycholate $1 \mathrm{mg} / \mathrm{kg}$

(alternating days)

MF $100 \mathrm{mg} / \mathrm{kg}$

PM $15 \mathrm{mg} / \mathrm{kg} / \mathrm{day}$

SSG $20 \mathrm{mg} / \mathrm{kg} /$ day

MA $20 \mathrm{mg} / \mathrm{kg} /$ day

L-Amb $5 \mathrm{mg} / \mathrm{kg}+$ MF $100 \mathrm{mg} / \mathrm{kg}$

L-Amb $5 \mathrm{mg} / \mathrm{kg}+\mathrm{PM} 15 \mathrm{mg} / \mathrm{kg} /$ day

MF $100 \mathrm{mg} / \mathrm{kg}+\mathrm{PM} 15 \mathrm{mg} / \mathrm{kg} /$ day

SSG $20 \mathrm{mg}+\mathrm{PM} 15 \mathrm{mg} / \mathrm{kg} /$ day

*Calculations for SSG and MF based on exchange rate of $€ 1=$ US $\$ 1.40$ (December 2013). Price range of MF depends on order volume. Price is based on generic SSG, World Health Organization (59).

L-Amb, liposomal amphotericin B; MF, miltefosine; PM, paromomycin; SSG, sodium stibogluconate; MA, meglumine antimoniate. 


\section{COMBINED DRUG THERAPY}

In general, the treatment of VL is clinically challenging, and the drugs have several drawbacks. Over the past few years, the WHO consensus has evolved toward the use of combination regimens, particularly in highly endemic regions. Combining drugs from various chemical classes has the following objectives: (i) shortening the duration of treatment, reducing total parenteral drug doses with fewer toxic effects, and improving adherence to the regimen; (ii) lowering the cost of the treatment (less burden on the health system), thus providing a more cost-effective option, and (iii) helping to delay the emergence of resistance. These strategies could increase the therapeutic lifespan of the respective drugs, as has been demonstrated with drugs for diseases like malaria, tuberculosis, and HIV. These strategies might also encourage a cure, especially in complicated cases like Leishmania-HIV coinfection, for which treatment outcomes with monotherapy have been consistently poor $(1,59,66)$.

Recently, reports of treatment failure with $\mathrm{Sb}^{\mathrm{V}}$ from the Indian subcontinent have increasingly raised the issue of acquired drug resistance (67). This concern also extends to miltefosine, which is worrisome given the drug's long half-life (84). More recently (95) reported unresponsiveness to liposomal amphotericin B in Sudanese patients, who experienced cured disease only with combination treatment. Specifically, a 17-day combination of antimonials with paromomycin presented 93\% efficacy in East Africa. Combination regimens including liposomal amphotericin B (single dose), paromomycin, and/or miltefosine were also found to be extremely effective (98-99\%) and safe, and are now included in WHO guidelines for the Indian subcontinent (see Table 1) $(1,59)$.

Substantial progress has been made in the chemotherapeutic approaches in recent years, but the current conventional drugs for VL are far from ideal (96). Combined therapy enhancement should be on-going, but exploratory studies that encompass highly efficient regimens in single dose treatments are urgently needed (97). The most effective strategies for protecting against resistance are uncertain, but overall monitoring of access to anti-leishmanial drugs should definitely be strengthened. In this context, canine treatment is still controversial, and strict action should be taken particularly for zoonotic VL. Worryingly, in Europe, dogs with active VL are routinely treated with first-line drugs for HVL, and this practice could generate parasites that are resistant to conventional therapies (98). Considering the success of combined therapy, the control and the effectiveness of current conventional medicines must be protected until new options arise.

\section{PROMISING STRATEGIES FOR VL TREATMENT: IMMUNOTHERAPY AND IMMUNOCHEMOTHERAPY}

The immunotherapy, involves the use of biological substances or molecules to modulate the immune responses for the purpose of achieving a prophylactic and/or therapeutic success. Currently, immunotherapy is a strategy applied against various diseases such as cancer, allergies, and some viruses (hepatitis). It is based on the idea that our organism's defense systems are capable of protecting us against a variety of diseases (in most circumstances). Normally, it is known that disease occurs when there is either a failure, suboptimal, or excessive immune response and this could be remedied by appropriate immune modulation or interventions using immunomodulatory agents or biological response modifiers. Thus, immunotherapeutic agents can exert their effect by directly or indirectly augmenting the host natural defenses, restoring the impaired effectors functions or decreasing host excessive response (99-101). Moreover, the combination of immunotherapy with chemotherapeutic drugs (immunochemotherapy), especially when applied against infectious diseases, results in an increased synergic action with activation of the immune system and direct action of drugs against the infectious agent. Therefore, immunotherapy and immunochemotherapy have been used to accelerate the specific immunity in responsive and non-responsive patients $(102,103)$. The underlying idea is to selectively induce Th1 responses that are fundamental for resistance in VL. Protective immunity usually follows recovery from leishmaniasis in immunocompetent patients, but the behavior of disease in these individuals suggests that their immune responses are not sterile. VL has emerged as an important opportunistic infection associated with HIV, with the risk of developing active/severe disease increasing 100-2320 times the average (20). Depending on the stage of infection and the clinical condition, the use of conventional chemotherapy can be inefficient. In such cases, combination therapy with immunomodulators that potentiate the cellular immune response can lead to more satisfactory results.

Immunotherapy with or without chemotherapy has been used for the treatment of cutaneous leishmaniasis (CL) in the last two decades. Convit et al. (104), using three injections of a vaccine composed of a lysate of L. mexicana amazonensis with BCG as an adjuvant, demonstrated a $94 \%$ of cure rates in CL patients in Venezuela. These authors also showed that 5341 patients from four different regions of Venezuela, who had different forms of CL (mucosal and chronic CL) and received the vaccine treatment between 1990 and 1999, demonstrated a high cure rate (91.2-98.7\%) (105). In Brazil, Mayrink et al. (106) evaluated an immunotherapy protocol using a mixture of five strains of Leishmania vaccine and observed a $76 \%$ cure rate in patients with CL. Moreover, years later, Mayrink et al. (107) used repeated daily doses of killed L. amazonensis in a human clinical trial comprising 542 patients and observed that $98.1 \%$ of the individuals treated with immunotherapy ( $n=53$; L. amazonensis vaccine $+\mathrm{BCG})$ showed a clinical cure. A similar cure rate was found in patients treated with conventional chemotherapy and an immunochemotherapy scheme (100\%). The immunochemotherapy protocol was also associated with a reduction in the total volume of the drug used $(17.9 \%)$ and a shorter treatment time (94.6 days for chemotherapy alone to 64.7 days for immunochemotherapy) (107). In the Sudan, a trial involving patients with persistent post-kala-azar dermal leishmaniasis and using a vaccine composed of a mixture of killed L. major adsorbed on alum + BCG, given four times at weekly intervals, showed that the cure rate with immunochemotherapy was significantly higher than with chemotherapy alone (final cure rates: 87 and 53\%, respectively) (108).

As we observed, therapeutic vaccines in CL can be rapidly evaluated at lower cost, appear to be safe, and are not associated with the adverse effects of conventional treatment, encouraging the use of this strategy for treatment of VL. Furthermore, using immunomodulators to enhance host immunity combined with conventional chemotherapy may have several advantages 
Table 3 | Immunotherapy and immunochemotherapy strategies against VL for humans and dogs

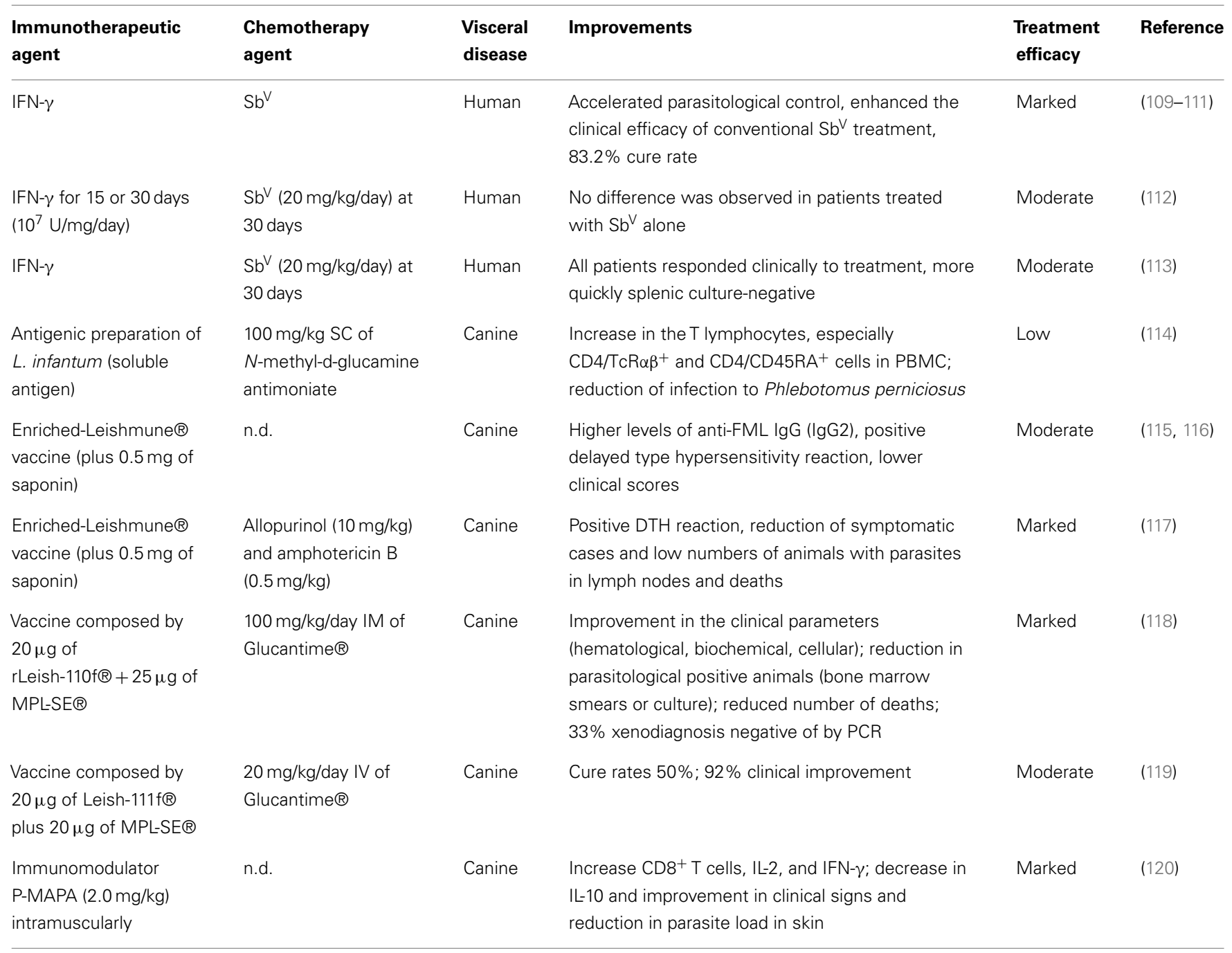

SC, subcutaneous; IM, intramuscular; IV, intravenous; n.d., not done.

as a means to improve current therapeutic regimens in this neglected disease (109). On this topic, we discuss advances in immunotherapy and immunochemotherapy for VL by focusing mainly on approaches used in humans and dogs (Table 3) and recent advances in murine models.

\section{APPROACHES USED IN HUMANS}

Increasing reports of treatment failure $\left(\mathrm{Sb}^{\mathrm{V}}\right.$, miltefosine, and liposomal amphotericin B) and complicated cases (Leishmania-HIV co-infection) in HVL increase the urgency of using combination therapies and developing new treatment strategies for the disease $(67,95)$. In fact, the added effects produced by immunotherapy and/or immunochemotherapy could be potentially useful against HVL; however, these approaches are still very rarely used.

In this context, IFN- $\gamma$ is well-recognized as a cytokine capable of inducing macrophages to kill intracellular Leishmania (110). It is clinically well-tolerated (111), and repeat treatment with IFN- $\gamma$ plus $\mathrm{Sb}^{\mathrm{V}}$ has been shown to be effective in patients with $\mathrm{Sb}^{\mathrm{V}}$ refractive disease, yielding a $>80 \%$ cure rate in VL $(112,113,121)$.
Studies in untreated patients with VL demonstrated that the addition of IFN- $\gamma$ as immunotherapy accelerated parasitological control $(122,123)$ and enhanced the clinical efficacy of conventional $\mathrm{Sb}^{\mathrm{V}}$ therapy (123). However, another human trial in India showed no differences among patients treated with $\mathrm{Sb}^{\mathrm{V}}$ alone (30 days, $20 \mathrm{mg} / \mathrm{kg} /$ day), $\mathrm{Sb}^{\mathrm{V}}$ plus IFN- $\gamma$ (30 days, $10^{7} \mathrm{U} / \mathrm{mg} /$ day), or $\mathrm{Sb}^{\mathrm{V}}$ plus IFN- $\gamma$ for 15 days (114). Six months after treatment, a low percentage of individuals were cured $(36,49,42 \%$, respectively), but the immunochemotherapy protocol was the most efficient.

A similar study was conducted in Kenyan patients with VL treated for 30 days with either conventional therapy with $\mathrm{Sb}^{\mathrm{V}}$ or immunochemotherapy (daily $\mathrm{Sb}^{\mathrm{V}}$ plus IFN- $\gamma$ ) (122). All patients responded clinically to treatment, and microscopic splenic aspirate scores rapidly decreased in both groups. Interestingly, the patients treated with immunochemotherapy had a negative spleen culture more quickly, which may demonstrate the potential of this protocol to accelerate early parasitological control (122). These results suggest the beneficial effects of using IFN- $\gamma$ in the treatment of HVL. The combination of this immunotherapy or 
another (therapeutic vaccines, immunomodulators) with other drugs (miltefosine, liposomal amphotericin B) could provide more satisfactory results with better cure rates mainly in VL patients unresponsive to $\mathrm{Sb}^{\mathrm{V}}$.

\section{PROGRESS FOR VL TREATMENT IN DOGS}

The drugs generally used to treat CVL are highly toxic, expensive, and ineffective. They promote clinical remission without parasite reduction or sterilization, and once the treatment is withdrawn, relapses of the disease are always observed (115). Moreover, the WHO does not recommend the use of human chemotherapy in dogs due to concerns about selecting for drug-resistant parasites, which might then be untreatable in subsequent HVL infection. Also, primary resistance to these drugs is considerable, and treated dogs still have parasites in different organs even if they are asymptomatic (116).

Along with vaccine development, new drugs and new treatment strategies (immunotherapy and immunochemotherapy) are the most important alternatives for CVL control. Guarga et al. (117) evaluated the efficacy of a novel immunochemotherapy protocol in dogs naturally infected with L. infantum. The protocol consisted of 21 consecutive subcutaneous injections of $N$-methylD-glucamine antimoniate $(100 \mathrm{mg} / \mathrm{kg})$ and three applications of an antigenic preparation of L. infantum (soluble antigen). The animals showed an increase in the proportion of $\mathrm{T}$ lymphocytes, especially of CD4/TcR $\alpha \beta^{+}$and CD4/CD45RA ${ }^{+}$cells in PBMCs, and reduction in the infection from Phlebotomus perniciosus after immunochemotherapy (117).

Different studies are being done to evaluate the potential of fucose-manose-ligand (FML) antigen plus saponin as an immunotherapy. Borja-Cabrera et al. (118) used three vaccine doses (1.5 mg FML $+1 \mathrm{mg}$ saponin) in asymptomatic dogs and observed them for 22 months after immunotherapy was complete. No deaths due to disease were recorded, and $90 \%$ of the dogs remained asymptomatic, healthy, and parasite free. In contrast, $37 \%$ of kala-azar deaths were recorded in nontreated animals (118). Another vaccine formulation (enrichedLeishmune ${ }^{\circledR}$ vaccine plus $0.5 \mathrm{mg}$ of saponin) was evaluated by Santos et al. (119) in dogs experimentally infected with L. infantum. The enriched-Leishmune was injected when dogs were seropositive and symptomatic. After immunotherapy, the dogs showed higher levels of anti-FML IgG (higher IgG2 and lower IgG1), positive delayed type hypersensitivity reactions, lower clinical scores, and normal $\mathrm{CD}^{+}{ }^{+}$counts (119). The association of enriched-Leishmune vaccine with chemotherapy (allopurinol or amphotericin B/allopurinol) demonstrated synergistic efficacy in naturally infected animals. For both immunotherapy and immunochemotherapy, dogs showed an intradermal response to Leishmania antigen, reduction of symptomatic cases, a lower proportion of animals presenting with parasites in lymph nodes, and fewer deaths (120).

Miret et al. (124) evaluated immunochemotherapy using Leish$110 \mathrm{f}^{\circledR}+\mathrm{MPL}-\mathrm{SE}{ }^{\circledR}$ vaccine in combination with Glucantime ${ }^{\circledR}$ and showed in symptomatic dogs improved clinical parameters (hematological, biochemical, and immunological), reduced parasite-positive animals, and reduced number of deaths compared to control groups (adjuvant alone or placebo). Trigo et al.
(125) performed two separate trials to evaluate the recombinant polyprotein vaccine antigen Leish- $111 \mathrm{f}^{\circledR}$, formulated with MPL$\mathrm{SE}^{\circledR}$ for therapeutic purposes against CVL. In both trials, a therapeutic efficacy of the vaccine in preventing mild cases of disease was demonstrated, and weekly injections (three doses) promoted clinical cure for many dogs with VL.

Using an immunomodulator, Santiago et al. (126) tested the immunotherapeutic effect for CVL of a protein aggregate of magnesium-ammonium phospholinoleate-palmitoleate anhydride (P-MAPA) obtained by fermenting the fungus Aspergillus oryzae. P-MAPA showed immunomodulatory activity, with greater stimulation of cellular immunity and no toxic effects in mice and dogs (127). To investigate the immunotherapeutic potential of P-MAPA, symptomatic dogs were submitted to a protocol of 15 doses of the immunomodulator $(2.0 \mathrm{mg} / \mathrm{kg})$ intramuscularly. An increase in $\mathrm{CD}^{+} \mathrm{T}$ cells in peripheral blood, a decrease in IL-10 levels, and an increase in IL- 2 and IFN- $\gamma$, improved clinical signs, and reduced skin parasitism were obtained after immunotherapy (126).

Some CVL vaccines candidates have been developed by our research group, called LBSap and LBSapSal, demonstrating important results of immunogenicity and efficacy in phase I and II trials $(128,129)$. Currently, we are investigating the potential immunotherapeutic of these and other vaccines in the treatment of CVL. Given these results, we believe that we could use immunotherapy/immunochemotherapy to treat dogs in endemic areas to eliminate their reservoir condition mainly by decreasing the skin parasite load, which would block the zoonotic transmission cycle.

\section{RECENTS ADVANCES IN MURINE MODELS}

With the current status of Leishmania treatment, use of a lowdose drug or a short course of an effective drug in combination with an immunomodulator is an approach for effective treatment of disease (130). Thus, murine models of leishmaniasis are being extensively used to obtain preliminary information on the anti-Leishmania potential of different compounds (67). Many researchers have worked on the development and discovery of new agents against the parasite, and several studies have shown that the use of immunotherapy would be an important tool in control of VL.

Because $\mathrm{Sb}^{\mathrm{V}}$-based anti-leishmanial chemotherapy depends in part on the Th1 response, which can be induced by dendritic cell (DC)-based treatment (131). DC-based immunotherapy combined with $\mathrm{Sb}^{\mathrm{V}}$ chemotherapy was very effective against murine VL (132). While three weekly injections of $L$. donovani-soluble, antigen-pulsed syngeneic bone marrow-derived DCs into mice infected with $L$. donovani only reduced the number of spleen and liver amastigotes, when combined with sodium stibogluconate, the treatment resulted in a complete eradication of the parasites from both organs (132).

A fusion protein that stimulates $\mathrm{T}$ cells through OX40, as well as a monoclonal antibody ( $\mathrm{mAb}$ ) agonist against CD40, enhanced host immunity, and supported low-dose $\mathrm{Sb}^{\mathrm{V}}$ in a murine VL model $(133,134)$. The treatment enhanced both the rate of granuloma maturation and $\mathrm{CD} 4^{+} \mathrm{T}$ cell proliferation and promoted greater reduction in the parasite burden, without causing excess 
tissue damage. Moreover, the blockade of cytotoxic T lymphocyteassociated (CTLA)-4, a negative regulator of $\mathrm{T}$ cell co-stimulation using $\mathrm{mAb}$, has a beneficial effect in experimental VL, inducing the destruction of $60 \%$ of the parasites within liver macrophages, stimulating IFN- $\gamma$ secretion, and enhancing mononuclear cell recruitment with significant synergy with $\mathrm{Sb}^{\mathrm{V}}$ (134).

In VL, cytokine-mediated immunosuppression is dominated by IL-10 and TGF- $\beta$ (135). Hence IL-10-deficient mice are highly resistant to VL $(27,135)$. This cytokine also impairs responsiveness to $\mathrm{Sb}^{\mathrm{V}}$. In experimental models of $\mathrm{VL}$, treatment with $\mathrm{mAb}$ against the IL-10 receptor allowed a 10 -fold reduction in the effective dose of $\mathrm{Sb}^{\mathrm{V}}$ compared with the drug alone, as well as considerable shortening of the time needed for effective therapy $(135,136)$. Inhibition of TGF- $\beta$ has been shown to decrease parasite burdens in experimental VL; however, TGF- $\beta$ blockade has no apparent effect on $\mathrm{Sb}^{\mathrm{V}}$ activity (136).

Using lower doses of miltefosine in combination with Pam3Cys (an immunomodulator synthetic bacterial lipopeptide (BLP) and TLR-2/1 ligand) in a BALB/c mouse model of VL, Shakya et al. (137) demonstrated significantly enhanced parasitic inhibition and Th1 cytokine production and an increased phagocytosis index. Another study, conducted by Karmakar et al. (138), demonstrated the interactions between a TLR ligand and invariant natural killer $\mathrm{T}$ (iNKT) cell activation as immunotherapy in VL. The authors evaluated the anti-Leishmania immune responses and the protective efficacy of the b-(1-4)-galactose terminal NKT cell ligand glycosphingophospholipid (GSPL) antigen of $L$. donovani parasites. Their findings suggested that TLR4 can function as an upstream sensor for GSPL and promote intracellular inflammatory signaling necessary for parasite killing. Furthermore, the treatment with GSPL induced a strong, effective $\mathrm{T}$ cell response, with control of acute parasite burden leading to undetectable parasite persistence (138).

The remarkable improvement in clinical signs and decrease in parasite burden in the immunotherapy or immunochemotherapy protocols described mostly arise from the restoration and activation of an effective immune response. In this context, the search for new therapeutic vaccines or substances with strong immunomodulatory effects as adjuvants (immunotherapy) may lead to the next generation of drugs, and associations with conventional chemotherapy (immunochemotherapy) will form the treatment strategy to cure visceral disease or reverse severe clinical forms of HVL.

\section{CONCLUDING REMARIS}

Most traditional and low-cost treatment options for VL are toxic and have many side effects, and the use of more effective drugs is limited mainly by the high cost. Successful immunotherapy using killed parasite vaccines or immunomodulators has been extensively reported in leishmaniasis. Another approach is immunochemotherapy, in which a low-dose or short course of chemotherapy associated with a vaccine or immunomodulator quickly induces an effective immune response. In VL, many efforts in the development and application of immunotherapy or immunochemotherapy have been made in the last decade, mainly due to the emergence of drug resistance and the increase in HIV co-infection. Many researchers have treated CVL using vaccines and immunomodulators with or without chemotherapy. In humans, the use of cytokines like IFN- $\gamma$ associated with $\mathrm{Sb}^{\mathrm{V}}$ has demonstrated promising results in patients that are unresponsive to conventional treatment. In murine models, immunomodulation based on mAbs to remove endogenous immunosuppressive cytokines or block their receptors, antigen-pulsed syngeneic DCs, and biological products like Pam3Cys (TLR ligand) has demonstrated future prospects for the treatment of VL. Efforts need to be directed to standardization and additional carefully controlled studies in animals and humans to understand the immunologic basis of these new vaccines and other immunomodulators in conjunction with chemotherapeutic agents for treatment of this important neglected disease.

\section{ACKNOWLEDGMENTS}

The authors are grateful for the Federal University of Ouro Preto (UFOP). This study was supported by the following grants: FAPEMIG grant: CNPq/BR/grant: 554757/2010-9; 476951/20135; GENOPROT 560943/2010-5; PPSUS/MS/CNPq/FAPEMIG/SESMG/grant CBB-APQ-00356-10; APQ-01358-12. Alexandre Barbosa Reis, Rodolfo Cordeiro Giunchetti, and Cláudia Martins Carneiro are grateful for CNPq fellowships, Wendel Coura-Vital and Nádia das Dores Moreira are grateful to the PNPD/CAPES fellowships and Bruno Mendes Roatt is grateful to the CNPq/DTI-A fellowship.

\section{REFERENCES}

1. van Griensven J, Diro E. Visceral leishmaniasis. Infect Dis Clin North Am (2012) 26(2):309-22. doi:10.1016/j.idc.2012.03.005

2. Dujardin JC, Campino L, Canavate C, Dedet JP, Gradoni L, Soteriadou K, et al. Spread of vector-borne diseases and neglect of leishmaniasis, Europe. Emerg Infect Dis (2008) 14(7):1013-8. doi:10.3201/eid1407.071589

3. Desjeux P. Leishmaniasis: current situation and new perspectives. Comp Immunol Microbiol Infect Dis (2004) 27(5):305-18. doi:10.1016/j.cimid.2004. 03.004

4. Laurenti MD, Rossi CN, Matta VL, Tomokane TY, Corbett CE, Secundino NF, et al. Asymptomatic dogs are highly competent to transmit Leishmania (Leishmania) infantum chagasi to the natural vector. Vet Parasitol (2013) 196(34):296-300. doi:10.1016/j.vetpar.2013.03.017

5. Molina R, Amela C, Nieto J, San-Andres M, Gonzalez F, Castillo JA, et al. Infectivity of dogs naturally infected with Leishmania infantum to colonized Phlebotomus perniciosus. Trans R Soc Trop Med Hyg (1994) 88(4):491-3. doi:10.1016/0035-9203(94)90446-4

6. Solano-Gallego L, Koutinas A, Miro G, Cardoso L, Pennisi MG, Ferrer L, et al. Directions for the diagnosis, clinical staging, treatment and prevention of canine leishmaniosis. Vet Parasitol (2009) 165(1-2):1-18. doi:10.1016/j.vetpar. 2009.05.022

7. Dantas-Torres F, Solano-Gallego L, Baneth G, Ribeiro VM, de Paiva-Cavalcanti M, Otranto D. Canine leishmaniosis in the Old and New Worlds: unveiled similarities and differences. Trends Parasitol (2012) 28(12):531-8. doi:10.1016/j. pt.2012.08.007

8. Freeman KS, Miller MD, Breitschwerdt EB, Lappin MR. Leishmaniasis in a dog native to Colorado. J Am Vet Med Assoc (2010) 237(11):1288-91. doi:10.2460/javma.237.11.1288

9. Duprey ZH, Steurer FJ, Rooney JA, Kirchhoff LV, Jackson JE, Rowton ED, et al. Canine visceral leishmaniasis, United States and Canada, 2000-2003. Emerg Infect Dis (2006) 12(3):440-6. doi:10.3201/eid1203.050811

10. Baldelli R, Piva S, Salvatore D, Parigi M, Melloni O, Tamba M, et al. Canine leishmaniasis surveillance in a northern Italy kennel. Vet Parasitol (2011) 179(13):57-61. doi:10.1016/j.vetpar.2011.01.052

11. Maroli M, Rossi L, Baldelli R, Capelli G, Ferroglio E, Genchi C, et al. The northward spread of leishmaniasis in Italy: evidence from retrospective and ongoing studies on the canine reservoir and phlebotomine vectors. Trop Med Int Health (2008) 13(2):256-64. doi:10.1111/j.1365-3156.2007.01998.x 
12. Malaquias LC, do Carmo Romualdo R, do Anjos JB Jr, Giunchetti RC, Correa-Oliveira R, Reis AB. Serological screening confirms the re-emergence of canine leishmaniosis in urban and rural areas in Governador Valadares, Vale do Rio Doce, Minas Gerais, Brazil. Parasitol Res (2007) 100(2):233-9. doi:10.1007/s00436-006-0259-z

13. Solano-Gallego L, Morell P, Arboix M, Alberola J, Ferrer L. Prevalence of Leishmania infantum infection in dogs living in an area of canine leishmaniasis endemicity using PCR on several tissues and serology. J Clin Microbiol (2001) 39(2):560-3. doi:10.1128/JCM.39.2.560-563.2001

14. Coura-Vital W, Marques MJ, Veloso VM, Roatt BM, Aguiar-Soares RD, Reis LE, et al. Prevalence and factors associated with Leishmania infantum infection of dogs from an urban area of Brazil as identified by molecular methods. PLoS Negl Trop Dis (2011) 5(8):e1291. doi:10.1371/journal.pntd. 0001291

15. Coura-Vital W, Reis AB, Fausto MA, Leal GG, Marques MJ, Veloso VM, et al. Risk factors for seroconversion by Leishmania infantum in a Cohort of dogs from an endemic area of Brazil. PLoS One (2013) 8(8):e71833. doi:10.1371/journal.pone.0071833

16. Coura-Vital W, Reis AB, Reis LE, Braga SL, Roatt BM, Aguiar-Soares RD, et al. Canine visceral leishmaniasis: incidence and risk factors for infection in a cohort study in Brazil. Vet Parasitol (2013) 197(3-4):411-7. doi:10.1016/j. vetpar.2013.07.031

17. Alvar J, Velez ID, Bern C, Herrero M, Desjeux P, Cano J, et al. Leishmaniasis worldwide and global estimates of its incidence. PLoS One (2012) 7(5):e35671. doi:10.1371/journal.pone.0035671

18. Gramiccia M, Scalone A, Di Muccio T, Orsini S, Fiorentino E, Gradoni L. The burden of visceral leishmaniasis in Italy from 1982 to 2012: a retrospective analysis of the multi-annual epidemic that occurred from 1989 to 2009 . Euro Surveill (2013) 18(29):20535.

19. Bogdan C, Schonian G, Banuls AL, Hide M, Pratlong F, Lorenz E, et al. Visceral leishmaniasis in a German child who had never entered a known endemic area: case report and review of the literature. Clin Infect Dis (2001) 32(2):302-6. doi:10.1086/318476

20. Alvar J, Aparicio P, Aseffa A, Den Boer M, Canavate C, Dedet JP, et al. The relationship between leishmaniasis and AIDS: the second 10 years. Clin Microbiol Rev (2008) 21(2):334-59. doi:10.1128/CMR.00061-07

21. Pintado V, Martin-Rabadan P, Rivera ML, Moreno S, Bouza E. Visceral leishmaniasis in human immunodeficiency virus (HIV)-infected and nonHIV-infected patients. A comparative study. Medicine (Baltimore) (2001) 80(1):54-73. doi:10.1097/00005792-200101000-00006

22. Murray HW, Berman JD, Davies CR, Saravia NG. Advances in leishmaniasis. Lancet (2005) 366(9496):1561-77. doi:10.1016/S0140-6736(05)67629-5

23. Costa DL, Rocha RL, Carvalho RM, Lima-Neto AS, Harhay MO, Costa CH, et al. Serum cytokines associated with severity and complications of kalaazar. Pathog Glob Health (2013) 107(2):78-87. doi:10.1179/2047773213Y. 0000000078

24. Ahluwalia IB, Bern C, Costa C, Akter T, Chowdhury R, Ali M, et al. Visceral leishmaniasis: consequences of a neglected disease in a Bangladeshi community. Am J Trop Med Hyg (2003) 69(6):624-8.

25. Barnett PG, Singh SP, Bern C, Hightower AW, Sundar S. Virgin soil: the spread of visceral leishmaniasis into Uttar Pradesh, India. Am J Trop Med Hyg (2005) 73(4):720-5.

26. Ministério da saúde. Sistema de Informação de Agravos de Notificação - Sinan Net. (2013) [cited 2013 December 2]. Available from: http://dtr2004.saude.gov. $\mathrm{br} /$ sinanweb/tabnet/tabnet?sinannet/leishvi/bases/leishvbrnet.def

27. Kaye PM, Svensson M, Ato M, Maroof A, Polley R, Stager S, et al. The immunopathology of experimental visceral leishmaniasis. Immunol Rev (2004) 201:239-53. doi:10.1111/j.0105-2896.2004.00188.x

28. Stager S, Joshi T, Bankoti R. Immune evasive mechanisms contributing to persistent Leishmania donovani infection. Immunol Res (2010) 47(1-3):14-24. doi:10.1007/s12026-009-8135-4

29. Nylen S, Gautam S. Immunological perspectives of leishmaniasis. J Glob Infect Dis (2010) 2(2):135-46. doi:10.4103/0974-777X.62876

30. Carvalho EM, Bacellar O, Barral A, Badaro R, Johnson WD Jr. Antigen-specific immunosuppression in visceral leishmaniasis is cell mediated. J Clin Invest (1989) 83(3):860-4. doi:10.1172/JCI113969

31. Bacellar O, Brodskyn C, Guerreiro J, Barral-Netto M, Costa CH, Coffman $\mathrm{RL}$, et al. Interleukin-12 restores interferon-gamma production and cytotoxic responses in visceral leishmaniasis. J Infect Dis (1996) 173(6):1515-8. doi:10. 1093/infdis/173.6.1515

32. Nylen S, Sacks D. Interleukin-10 and the pathogenesis of human visceral leishmaniasis. Trends Immunol (2007) 28(9):378-84. doi:10.1016/j.it.2007.07.004

33. Pinelli E, Killick-Kendrick R, Wagenaar J, Bernadina W, del Real G, Ruitenberg J. Cellular and humoral immune responses in dogs experimentally and naturally infected with Leishmania infantum. Infect Immun (1994) 62(1): 229-35.

34. Pinelli E, van der Kaaij SY, Broeren CP, Ruitenberg EJ, Rutten VP. Measurement of dog cytokines by reverse transcription-quantitative competitive polymerase chain reaction. Immunogenetics (1999) 49(7-8):696-9. doi:10.1007/ s002510050667

35. Reis AB, Martins-Filho OA, Teixeira-Carvalho A, Carvalho MG, Mayrink W, Franca-Silva JC, et al. Parasite density and impaired biochemical/hematological status are associated with severe clinical aspects of canine visceral leishmaniasis. Res Vet Sci (2006) 81(1):68-75. doi:10.1016/j.rvsc.2005.09.011

36. Reis AB, Martins-Filho OA, Teixeira-Carvalho A, Giunchetti RC, Carneiro CM, Mayrink W, et al. Systemic and compartmentalized immune response in canine visceral leishmaniasis. Vet Immunol Immunopathol (2009) 128(1-3):87-95. doi:10.1016/j.vetimm.2008.10.307

37. Bhattacharya P, Ali N. Involvement and interactions of different immune cells and their cytokines in human visceral leishmaniasis. Rev Soc Bras Med Trop (2013) 46(2):128-34. doi:10.1590/0037-8682-0022-2012

38. Peruhype-Magalhaes V, Martins-Filho OA, Prata A, Silva Lde A, Rabello A, Teixeira-Carvalho A, et al. Immune response in human visceral leishmaniasis: analysis of the correlation between innate immunity cytokine profile and disease outcome. Scand J Immunol (2005) 62(5):487-95. doi:10.1111/j.13653083.2005.01686.x

39. Manna PP, Chakrabarti G, Bandyopadhyay S. Innate immune defense in visceral leishmaniasis: cytokine mediated protective role by allogeneic effector cell. Vaccine (2010) 28(3):803-10. doi:10.1016/j.vaccine.2009.10.053

40. Murray HW. Endogenous interleukin-12 regulates acquired resistance in experimental visceral leishmaniasis. J Infect Dis (1997) 175(6):1477-9. doi:10.1086/ 516482

41. Bogdan C, Rollinghoff M, Diefenbach A. The role of nitric oxide in innate immunity. Immunol Rev (2000) 173:17-26. doi:10.1034/j.1600-065X.2000. 917307.x

42. Brandonisio O, Panaro MA, Fumarola I, Sisto M, Leogrande D, Acquafredda A, et al. Macrophage chemotactic protein-1 and macrophage inflammatory protein-1 alpha induce nitric oxide release and enhance parasite killing in Leishmania infantum-infected human macrophages. Clin Exp Med (2002) 2(3):125-9. doi:10.1007/s102380200017

43. Medeiros IM, Reed S, Castelo A, Salomao R. Circulating levels of sTNFR and discrepancy between cytotoxicity and immunoreactivity of TNF-alpha in patients with visceral leishmaniasis. Clin Microbiol Infect (2000) 6(1):34-7. doi:10.1046/j.1469-0691.2000.00011.x

44. Pitta MG, Romano A, Cabantous S, Henri S, Hammad A, Kouriba B, et al. IL17 and IL-22 are associated with protection against human kala azar caused by Leishmania donovani. J Clin Invest (2009) 119(8):2379-87. doi:10.1172/ JCI38813

45. Ansari NA, Kumar R, Gautam S, Nylen S, Singh OP, Sundar S, et al. IL-27 and IL-21 are associated with T cell IL-10 responses in human visceral leishmaniasis. J Immunol (2011) 186(7):3977-85. doi:10.4049/jimmunol.1003588

46. Gautam S, Kumar R, Singh N, Singh AK, Rai M, Sacks D, et al. CD8 T cell exhaustion in human visceral leishmaniasis. J Infect Dis (2014) 209(2):290-9. doi:10.1093/infdis/jit401

47. Racoosin EL, Beverley SM. Leishmania major: promastigotes induce expression of a subset of chemokine genes in murine macrophages. Exp Parasitol (1997) 85(3):283-95. doi:10.1006/expr.1996.4139

48. Antoniazi S, Price HP, Kropf P, Freudenberg MA, Galanos C, Smith DF, et al. Chemokine gene expression in toll-like receptor-competent and-deficient mice infected with Leishmania major. Infect Immun (2004) 72(9):5168-74. doi:10.1128/IAI.72.9.5168-5174.2004

49. Menezes-Souza D, Guerra-Sa R, Carneiro CM, Vitoriano-Souza J, Giunchetti RC, Teixeira-Carvalho A, et al. Higher expression of CCL2, CCL4, CCL5, CCL21, and CXCL8 chemokines in the skin associated with parasite density in canine visceral leishmaniasis. PLoS Negl Trop Dis (2012) 6(4):e1566. doi:10.1371/journal.pntd.0001566 
50. Stanley AC, Engwerda CR. Balancing immunity and pathology in visceral leishmaniasis. Immunol Cell Biol (2007) 85(2):138-47. doi:10.1038/sj.icb7100011

51. Hailu A, van der Poll T, Berhe N, Kager PA. Elevated plasma levels of interferon (IFN)-gamma, IFN-gamma inducing cytokines, and IFN-gamma inducible CXC chemokines in visceral leishmaniasis. Am J Trop Med Hyg (2004) 71(5):561-7.

52. Strauss-Ayali D, Baneth G, Jaffe CL. Splenic immune responses during canine visceral leishmaniasis. Vet Res (2007) 38(4):547-64. doi:10.1051/vetres: 2007015

53. Ritter U, Moll H. Monocyte chemotactic protein-1 stimulates the killing of Leishmania major by human monocytes, acts synergistically with IFNgamma and is antagonized by IL-4. Eur J Immunol (2000) 30(11):3111-20. doi:10.1002/1521-4141(200011)30:11<3111::AID-IMMU3111>3.0.CO;2-O

54. Trinchieri G. Cytokines acting on or secreted by macrophages during intracellular infection (IL-10, IL-12, IFN-gamma). Curr Opin Immunol (1997) 9(1):17-23. doi:10.1016/S0952-7915(97)80154-9

55. Kemp M, Kurtzhals JA, Kharazmi A, Theander TG. Interferon-gamma and interleukin-4 in human Leishmania donovani infections. Immunol Cell Biol (1993) 71(Pt 6):583-7. doi:10.1038/icb.1993.64

56. de Waal Malefyt R, Abrams J, Bennett B, Figdor CG, de Vries JE. Interleukin 10(IL-10) inhibits cytokine synthesis by human monocytes: an autoregulatory role of IL-10 produced by monocytes. J Exp Med (1991) 174(5):1209-20. doi:10.1084/jem.174.5.1209

57. de Waal Malefyt R, Haanen J, Spits H, Roncarolo MG, te Velde A, Figdor C, et al. Interleukin 10 (IL-10) and viral IL-10 strongly reduce antigen-specific human $\mathrm{T}$ cell proliferation by diminishing the antigen-presenting capacity of monocytes via downregulation of class II major histocompatibility complex expression. J Exp Med (1991) 174(4):915-24. doi:10.1084/jem.174.4.915

58. Scharton-Kersten T, Afonso LC, Wysocka M, Trinchieri G, Scott P. IL-12 is required for natural killer cell activation and subsequent $\mathrm{T}$ helper 1 cell development in experimental leishmaniasis. J Immunol (1995) 154(10):5320-30.

59. World Health Organization. Control of the Leishmaniasis: Report of a Meeting of the WHO Expert Committee on the Control of Leishmaniases. Geneva: WHO (2010). p. 202. Available from: http://whqlibdoc.who.int/trs/WHO_TRS_949_ eng.pdf

60. Singh N, Kumar M, Singh RK. Leishmaniasis: current status of available drugs and new potential drug targets. Asian Pac J Trop Med (2012) 5(6):485-97. doi:10.1016/S1995-7645(12)60084-4

61. Fraga DB, Solca MS, Silva VM, Borja LS, Nascimento EG, Oliveira GG, et al. Temporal distribution of positive results of tests for detecting Leishmania infection in stray dogs of an endemic area of visceral leishmaniasis in the Brazilian tropics: a 13 years survey and association with human disease. Vet Parasitol (2012) 190(3-4):591-4. doi:10.1016/j.vetpar.2012.06.025

62. Davidson RN, di Martino L, Gradoni L, Giacchino R, Gaeta GB, Pempinello R, et al. Short-course treatment of visceral leishmaniasis with liposomal amphotericin B (AmBisome). Clin Infect Dis (1996) 22(6):938-43. doi:10.1093/ clinids/22.6.938

63. Jha TK, Sundar S, Thakur CP, Bachmann P, Karbwang J, Fischer C, et al. Miltefosine, an oral agent, for the treatment of Indian visceral leishmaniasis. $N$ Engl J Med (1999) 341(24):1795-800. doi:10.1056/NEJM199912093412403

64. Sundar S, Jha TK, Thakur CP, Engel J, Sindermann H, Fischer C, et al. Oral miltefosine for Indian visceral leishmaniasis. N Engl J Med (2002) 347(22):1739-46. doi:10.1056/NEJMoa021556

65. Jha TK, Olliaro P, Thakur CP, Kanyok TP, Singhania BL, Singh IJ, et al. Randomised controlled trial of aminosidine (paromomycin) v sodium stibogluconate for treating visceral leishmaniasis in North Bihar, India. BMJ (1998) 316(7139):1200-5. doi:10.1136/bmj.316.7139.1200

66. Alvar J, Croft S, Olliaro P. Chemotherapy in the treatment and control of leishmaniasis. Adv Parasitol (2006) 61:223-74. doi:10.1016/S0065-308X(05) 61006-8

67. Croft SL, Sundar S, Fairlamb AH. Drug resistance in leishmaniasis. Clin Microbiol Rev (2006) 19(1):111-26. doi:10.1128/CMR.19.1.111-126.2006

68. Matoussi N, Ameur HB, Amor SB, Fitouri Z, Becher SB. Cardiotoxicity of nmethyl-glucamine antimoniate (Glucantime). A case report. Med Mal Infect (2007) 37(Suppl 3):S257-9. doi:10.1016/j.medmal.2007.08.001

69. Gasser RA Jr, Magill AJ, Oster CN, Franke ED, Grogl M, Berman JD. Pancreatitis induced by pentavalent antimonial agents during treatment of leishmaniasis. Clin Infect Dis (1994) 18(1):83-90. doi:10.1093/clinids/18.1.83
70. Zaghloul IY, Al-Jasser M. Effect of renal impairment on the pharmacokinetics of antimony in hamsters. Ann Trop Med Parasitol (2004) 98(8):793-800. doi:10.1179/000349804X3171

71. Mancianti F, Gramiccia M, Gradoni L, Pieri S. Studies on canine leishmaniasis control. 1. Evolution of infection of different clinical forms of canine leishmaniasis following antimonial treatment. Trans $R$ Soc Trop Med Hyg (1988) 82(4):566-7. doi:10.1016/0035-9203(88)90510-X

72. Slappendel RJ, Teske E. The effect of intravenous or subcutaneous administration of meglumine antimoniate (Glucantime) in dogs with leishmaniasis. A randomized clinical trial. Vet Q (1997) 19(1):10-3. doi:10.1080/01652176. 1997.9694729

73. Carrio J, Portus M. In vitro susceptibility to pentavalent antimony in Leishmania infantum strains is not modified during in vitro or in vivo passages but is modified after host treatment with meglumine antimoniate. BMC Pharmacol (2002) 2:11. doi:10.1186/1471-2210-2-11

74. da Silva SM, Amorim IF, Ribeiro RR, Azevedo EG, Demicheli C, Melo MN, et al. Efficacy of combined therapy with liposome-encapsulated meglumine antimoniate and allopurinol in treatment of canine visceral leishmaniasis. Antimicrob Agents Chemother (2012) 56(6):2858-67. doi:10.1128/AAC.00208-12

75. Lachaud L, Bourgeois N, Plourde M, Leprohon P, Bastien P, Ouellette M. Parasite susceptibility to amphotericin B in failures of treatment for visceral leishmaniasis in patients coinfected with HIV type 1 and Leishmania infantum. Clin Infect Dis (2009) 48(2):e16-22. doi:10.1086/595710

76. Sundar S, Chakravarty J, Rai VK, Agrawal N, Singh SP, Chauhan V, et al. Amphotericin B treatment for Indian visceral leishmaniasis: response to 15 daily versus alternate-day infusions. Clin Infect Dis (2007) 45(5):556-61. doi:10.1086/520665

77. Sinha PK, Roddy P, Palma PP, Kociejowski A, Lima MA, Rabi Das VN, et al. Effectiveness and safety of liposomal amphotericin B for visceral leishmaniasis under routine program conditions in Bihar, India. Am J Trop Med Hyg (2010) 83(2):357-64. doi:10.4269/ajtmh.2010.10-0156

78. Oliva G, Gradoni L, Ciaramella P, De Luna R, Cortese L, Orsini S, et al. Activity of liposomal amphotericin B (AmBisome) in dogs naturally infected with Leishmania infantum. J Antimicrob Chemother (1995) 36(6):1013-9. doi:10.1093/jac/36.6.1013

79. Rigo RS, Carvalho CM, Honer MR, Andrade GB, Silva IS, Rigo L, et al. Renal histopathological findings in dogs with visceral leishmaniasis. Rev Inst Med Trop Sao Paulo (2013) 55(2):113-6. doi:10.1590/S0036-46652013000200008

80. Cortadellas O. Initial and long-term efficacy of a lipid emulsion of amphotericin B desoxycholate in the management of canine leishmaniasis. J Vet Intern Med (2003) 17(6):808-12. doi:10.1111/j.1939-1676.2003.tb02518.x

81. Croft SL, Coombs GH. Leishmaniasis - current chemotherapy and recent advances in the search for novel drugs. Trends Parasitol (2003) 19(11):502-8. doi:10.1016/j.pt.2003.09.008

82. Sundar S, Jha TK, Thakur CP, Bhattacharya SK, Rai M. Oral miltefosine for the treatment of Indian visceral leishmaniasis. Trans $R$ Soc Trop Med Hyg (2006) 100(Suppl 1):S26-33. doi:10.1016/j.trstmh.2006.02.011

83. Verma NK, Dey CS. Possible mechanism of miltefosine-mediated death of Leishmania donovani. Antimicrob Agents Chemother (2004) 48(8):3010-5. doi:10.1128/AAC.48.8.3010-3015.2004

84. Sundar S, Olliaro PL. Miltefosine in the treatment of leishmaniasis: clinical evidence for informed clinical risk management. Ther Clin Risk Manag (2007) 3(5):733-40.

85. Perez-Victoria FJ, Gamarro F, Ouellette M, Castanys S. Functional cloning of the miltefosine transporter. A novel P-type phospholipid translocase from Leishmania involved in drug resistance. J Biol Chem (2003) 278(50):49965-71. doi:10.1074/jbc.M308352200

86. Andrade HM, Toledo VP, Pinheiro MB, Guimaraes TM, Oliveira NC, Castro $\mathrm{JA}$, et al. Evaluation of miltefosine for the treatment of dogs naturally infected with L. infantum (=L. chagasi) in Brazil. Vet Parasitol (2011) 181(2-4):83-90. doi:10.1016/j.vetpar.2011.05.009

87. Farca AM, Miniscalco B, Badino P, Odore R, Monticelli P, Trisciuoglio A, et al. Canine leishmaniosis: in vitro efficacy of miltefosine and marbofloxacin alone or in combination with allopurinol against clinical strains of Leishmania infantum. Parasitol Res (2012) 110(6):2509-13. doi:10.1007/s00436-011-2792-7

88. Woerly V, Maynard L, Sanquer A, Eun HM. Clinical efficacy and tolerance of miltefosine in the treatment of canine leishmaniosis. Parasitol Res (2009) 105(2):463-9. doi:10.1007/s00436-009-1404-2 
89. Hailu A, Musa A, Wasunna M, Balasegaram M, Yifru S, Mengistu G, et al. Geographical variation in the response of visceral leishmaniasis to paromomycin in East Africa: a multicentre, open-label, randomized trial. PLoS Negl Trop Dis (2010) 4(10):e709. doi:10.1371/journal.pntd.0000709

90. Sundar S, Chakravarty J. Paromomycin in the treatment of leishmaniasis. Expert Opin Investig Drugs (2008) 17(5):787-94. doi:10.1517/13543784.17.5. 787

91. Fernandez MM, Malchiodi EL, Algranati ID. Differential effects of paromomycin on ribosomes of Leishmania mexicana and mammalian cells. Antimicrob Agents Chemother (2011) 55(1):86-93. doi:10.1128/AAC.00506-10

92. Sundar S, Jha TK, Thakur CP, Sinha PK, Bhattacharya SK. Injectable paromomycin for visceral leishmaniasis in India. N Engl J Med (2007) 356(25):2571-81. doi:10.1056/NEJMoa066536

93. Poli A, Sozzi S, Guidi G, Bandinelli P, Mancianti F. Comparison of aminosidine (paromomycin) and sodium stibogluconate for treatment of canine leishmaniasis. Vet Parasitol (1997) 71(4):263-71. doi:10.1016/S03044017(97)00014-9

94. Vexenat JA, Olliaro PL, Fonseca de Castro JA, Cavalcante R, Furtado Campos $\mathrm{JH}$, Tavares JP, et al. Clinical recovery and limited cure in canine visceral leishmaniasis treated with aminosidine (paromomycin). Am J Trop Med Hyg (1998) 58(4):448-53.

95. Mueller M, Ritmeijer K, Balasegaram M, Koummuki Y, Santana MR, Davidson R. Unresponsiveness to AmBisome in some Sudanese patients with kala-azar. Trans R Soc Trop Med Hyg (2007) 101(1):19-24. doi:10.1016/j. trstmh.2006.02.005

96. Freitas-Junior LH, Chatelain E, Kim HA, Siqueira-Neto JL. Visceral leishmaniasis treatment: what do we have, what do we need and how to deliver it? Int J Parasitol Drugs Drug Resist (2012) 2:11-9. doi:10.1016/j.ijpddr.2012. 01.003

97. Sundar S, Chakravarty J. Leishmaniasis: an update of current pharmacotherapy. Expert Opin Pharmacother (2013) 14(1):53-63. doi:10.1517/14656566. 2013.755515

98. Oliva G, Roura X, Crotti A, Maroli M, Castagnaro M, Gradoni L, et al. Guidelines for treatment of leishmaniasis in dogs. J Am Vet Med Assoc (2010) 236(11):1192-8. doi:10.2460/javma.236.11.1192

99. Okwor I, Uzonna JE. Immunotherapy as a strategy for treatment of leishmaniasis: a review of the literature. Immunotherapy (2009) 1(5):765-76. doi:10.2217/imt.09.40

100. Oldham RK. Biologicals: new horizons in pharmaceutical development. J Biol Response Mod (1983) 2(3):199-206.

101. Oldham RK, Smalley RV. Immunotherapy: the old and the new. J Biol Response Mod (1983) 2(1):1-37.

102. El-On J. Current status and perspectives of the immunotherapy of leishmaniasis. Isr Med Assoc J (2009) 11(10):623-8.

103. Genaro O, de Toledo VP, da Costa CA, Hermeto MV, Afonso LC, Mayrink W. Vaccine for prophylaxis and immunotherapy, Brazil. Clin Dermatol (1996) 14(5):503-12. doi:10.1016/0738-081X(96)00040-5

104. Convit J, Castellanos PL, Rondon A, Pinardi ME, Ulrich M, Castes M, et al. Immunotherapy versus chemotherapy in localised cutaneous leishmaniasis. Lancet (1987) 1(8530):401-5. doi:10.1016/S0140-6736(87)90116-4

105. Convit J, Ulrich M, Zerpa O, Borges R, Aranzazu N, Valera M, et al. Immunotherapy of American cutaneous leishmaniasis in Venezuela during the period 1990-99. Trans $R$ Soc Trop Med Hyg (2003) 97(4):469-72. doi:10.1016/S0035-9203(03)90093-9

106. Mayrink W, Magalhaes PA, Michalick MS, da Costa CA, Lima Ade O, Melo $\mathrm{MN}$, et al. Immunotherapy as a treatment of American cutaneous leishmaniasis: preliminary studies in Brazil. Parassitologia (1992) 34(1-3):159-65.

107. Mayrink W, Botelho AC, Magalhaes PA, Batista SM, Lima Ade O, Genaro O, et al. Immunotherapy, immunochemotherapy and chemotherapy for American cutaneous leishmaniasis treatment. Rev Soc Bras Med Trop (2006) 39(1):14-21. doi:10.1590/S0037-86822006000100003

108. Musa AM, Khalil EA, Mahgoub FA, Elgawi SH, Modabber F, Elkadaru AE, et al. Immunochemotherapy of persistent post-kala-azar dermal leishmaniasis: a novel approach to treatment. Trans R Soc Trop Med Hyg (2008) 102(1):58-63. doi:10.1016/j.trstmh.2007.08.006

109. Dalton JE, Kaye PM. Immunomodulators: use in combined therapy against leishmaniasis. Expert Rev Anti Infect Ther (2010) 8(7):739-42. doi:10.1586/eri. 10.64
110. Murray HW, Rubin BY, Rothermel CD. Killing of intracellular Leishmania donovani by lymphokine-stimulated human mononuclear phagocytes. Evidence that interferon-gamma is the activating lymphokine. J Clin Invest (1983) 72(4):1506-10. doi:10.1172/JCI111107

111. Murray HW. Interferon-gamma and host antimicrobial defense: current and future clinical applications. Am J Med (1994) 97(5):459-67. doi:10.1016/00029343(94)90326-3

112. Sundar S, Rosenkaimer F, Murray HW. Successful treatment of refractory visceral leishmaniasis in India using antimony plus interferon-gamma. J Infect Dis (1994) 170(3):659-62. doi:10.1093/infdis/170.3.659

113. Badaro R. The use of recombinant gamma interferon associated with pentavalent antimony in therapy for visceral leishmaniasis. Mem Inst Oswaldo Cruz (1988) 83(Suppl 1):376-7. doi:10.1590/S0074-02761988000500028

114. Sundar S, Singh VP, Sharma S, Makharia MK, Murray HW. Response to interferon-gamma plus pentavalent antimony in Indian visceral leishmaniasis. J Infect Dis (1997) 176(4):1117-9. doi:10.1086/516526

115. Baneth G, Shaw SE. Chemotherapy of canine leishmaniosis. Vet Parasitol (2002) 106(4):315-24. doi:10.1016/S0304-4017(02)00115-2

116. Riera C, Valladares JE, Gallego M, Aisa MJ, Castillejo S, Fisa R, et al. Serological and parasitological follow-up in dogs experimentally infected with Leishmania infantum and treated with meglumine antimoniate. Vet Parasitol (1999) 84(1-2):33-47. doi:10.1016/S0304-4017(99)00084-9

117. Guarga JL, Moreno J, Lucientes J, Gracia MJ, Peribanez MA, Castillo JA. Evaluation of a specific immunochemotherapy for the treatment of canine visceral leishmaniasis. Vet Immunol Immunopathol (2002) 88(1-2):13-20. doi:10.1016/S0165-2427(02)00128-9

118. Borja-Cabrera GP, Cruz Mendes A, Paraguai de Souza E, Hashimoto Okada LY, de A Trivellato FA, Kawasaki JK, et al. Effective immunotherapy against canine visceral leishmaniasis with the FML-vaccine. Vaccine (2004) 22(1718):2234-43. doi:10.1016/j.vaccine.2003.11.039

119. Santos FN, Borja-Cabrera GP, Miyashiro LM, Grechi J, Reis AB, Moreira MA, et al. Immunotherapy against experimental canine visceral leishmaniasis with the saponin enriched-Leishmune vaccine. Vaccine (2007) 25(33):6176-90. doi:10.1016/j.vaccine.2007.06.005

120. Borja-Cabrera GP, Santos FN, Santos FB, Trivellato FA, Kawasaki JK, Costa $\mathrm{AC}$, et al. Immunotherapy with the saponin enriched-Leishmune vaccine versus immunochemotherapy in dogs with natural canine visceral leishmaniasis. Vaccine (2010) 28(3):597-603. doi:10.1016/j.vaccine.2009.09.071

121. Badaro R, Falcoff E, Badaro FS, Carvalho EM, Pedral-Sampaio D, Barral A, et al. Treatment of visceral leishmaniasis with pentavalent antimony and interferon gamma. N Engl J Med (1990) 322(1):16-21. doi:10.1056/ NEJM199001043220104

122. Squires KE, Rosenkaimer F, Sherwood JA, Forni AL, Were JB, Murray HW. Immunochemotherapy for visceral leishmaniasis: a controlled pilot trial of antimony versus antimony plus interferon-gamma. Am J Trop Med Hyg (1993) 48(5):666-9.

123. Sundar S, Murray HW. Effect of treatment with interferon-gamma alone in visceral leishmaniasis. J Infect Dis (1995) 172(6):1627-9. doi:10.1093/infdis/ 172.6.1627

124. Miret J, Nascimento E, Sampaio W, Franca JC, Fujiwara RT, Vale A, et al. Evaluation of an immunochemotherapeutic protocol constituted of N-methyl meglumine antimoniate (Glucantime) and the recombinant Leish-110f + MPL-SE vaccine to treat canine visceral leishmaniasis. Vaccine (2008) 26(12):1585-94. doi:10.1016/j.vaccine.2008.01.026

125. Trigo J, Abbehusen M, Netto EM, Nakatani M, Pedral-Sampaio G, de Jesus RS, et al. Treatment of canine visceral leishmaniasis by the vaccine Leish-111f+MPL-SE. Vaccine (2010) 28(19):3333-40. doi:10.1016/j.vaccine. 2010.02.089

126. Santiago ME, Neto LS, Alexandre EC, Munari DP, Andrade MM, Somenzari $\mathrm{MA}$, et al. Improvement in clinical signs and cellular immunity of dogs with visceral leishmaniasis using the immunomodulator P-MAPA. Acta Trop (2013) 127(3):174-80. doi:10.1016/j.actatropica.2013.04.005

127. Favaro WJ, Nunes OS, Seiva FR, Nunes IS, Woolhiser LK, Duran N, et al. Effects of P-MAPA immunomodulator on toll-like receptors and p53: potential therapeutic strategies for infectious diseases and cancer. Infect Agent Cancer (2012) 7(1):14. doi:10.1186/1750-9378-7-14

128. Roatt BM, Aguiar-Soares RD, Vitoriano-Souza J, Coura-Vital W, Braga SL, Correa-Oliveira $\mathrm{R}$, et al. Performance of LBSap vaccine after intradermal 
challenge with $L$. infantum and saliva of Lu. longipalpis: immunogenicity and parasitological evaluation. PLoS One (2012) 7(11):e49780. doi:10.1371/ journal.pone.0049780

129. Aguiar-Soares RD, Roatt BM, Ker HG, Moreira N, Mathias FA, Cardoso JM, et al. LBSapSal-vaccinated dogs exhibit increased circulating T-lymphocyte subsets $(\mathrm{CD} 4(+)$ and $\mathrm{CD} 8(+))$ as well as a reduction of parasitism after challenge with Leishmania infantum plus salivary gland of Lutzomyia longipalpis. Parasit Vectors (2014) 7:61. doi:10.1186/1756-3305-7-61

130. Musa AM, Noazin S, Khalil EA, Modabber F. Immunological stimulation for the treatment of leishmaniasis: a modality worthy of serious consideration. Trans R Soc Trop Med Hyg (2010) 104(1):1-2. doi:10.1016/j.trstmh.2009. 07.026

131. Moll H, Berberich C. Dendritic cell-based vaccination strategies: induction of protective immunity against leishmaniasis. Immunobiology (2001) 204(5):659-66. doi:10.1078/0171-2985-00105

132. Ghosh M, Pal C, Ray M, Maitra S, Mandal L, Bandyopadhyay S. Dendritic cellbased immunotherapy combined with antimony-based chemotherapy cures established murine visceral leishmaniasis. J Immunol (2003) 170(11):5625-9. doi:10.4049/jimmunol.170.11.5625

133. Murray HW, Lu CM, Brooks EB, Fichtl RE, DeVecchio JL, Heinzel FP. Modulation of T-cell costimulation as immunotherapy or immunochemotherapy in experimental visceral leishmaniasis. Infect Immun (2003) 71(11):6453-62. doi:10.1128/IAI.71.11.6453-6462.2003

134. Zubairi S, Sanos SL, Hill S, Kaye PM. Immunotherapy with OX40L-Fc or antiCTLA-4 enhances local tissue responses and killing of Leishmania donovani. Eur J Immunol (2004) 34(5):1433-40. doi:10.1002/eji.200324021

135. Murray HW, Lu CM, Mauze S, Freeman S, Moreira AL, Kaplan G, et al. Interleukin-10 (IL-10) in experimental visceral leishmaniasis and IL-10 receptor blockade as immunotherapy. Infect Immun (2002) 70(11):6284-93. doi:10. 1128/IAI.70.11.6284-6293.2002
136. Murray HW. Interleukin 10 receptor blockade - pentavalent antimony treatment in experimental visceral leishmaniasis. Acta Trop (2005) 93(3):295-301. doi:10.1016/j.actatropica.2004.11.008

137. Shakya N, Sane SA, Vishwakarma P, Gupta S. Enhancement in therapeutic efficacy of miltefosine in combination with synthetic bacterial lipopeptide, Pam3Cys against experimental visceral leishmaniasis. Exp Parasitol (2012) 131(3):377-82. doi:10.1016/j.exppara.2012.05.007

138. Karmakar S, Bhaumik SK, Paul J, De T. TLR4 and NKT cell synergy in immunotherapy against visceral leishmaniasis. PLoS Pathog (2012) 8(4):e1002646. doi:10.1371/journal.ppat.1002646

Conflict of Interest Statement: The authors declare that the research was conducted in the absence of any commercial or financial relationships that could be construed as a potential conflict of interest.

Received: 06 March 2014; accepted: 27 May 2014; published online: 13 June 2014.

Citation: Roatt BM, Aguiar-Soares RDdO, Coura-Vital W, Ker HG, Moreira NdD, Vitoriano-Souza J, Giunchetti RC, Carneiro CM and Reis AB (2014) Immunotherapy and immunochemotherapy in visceral leishmaniasis: promising treatments for this neglected disease. Front. Immunol. 5:272. doi: 10.3389/fimmu.2014.00272

This article was submitted to Immunotherapies and Vaccines, a section of the journal Frontiers in Immunology.

Copyright (c) 2014 Roatt, Aguiar-Soares, Coura-Vital, Ker, Moreira, Vitoriano-Souza, Giunchetti, Carneiro and Reis. This is an open-access article distributed under the terms of the Creative Commons Attribution License (CC BY). The use, distribution or reproduction in other forums is permitted, provided the original author(s) or licensor are credited and that the original publication in this journal is cited, in accordance with accepted academic practice. No use, distribution or reproduction is permitted which does not comply with these terms. 